\title{
Review
}

\section{Is there an association of allergy and cardiovascular disease?}

\author{
Katarzyna Bergmann*, Grazyna Sypniewska \\ Department of Laboratory Medicine, Nicolaus Copernicus University Collegium Medicum in Bydgoszcz, Bydgoszcz, Poland \\ *Corresponding author: bergmann@vp.pl
}

\begin{abstract}
Cardiovascular diseases and allergic diseases occur commonly in developed countries. They lead to serious health complications and significantly impair the quality of life. Both types of diseases are characterized by excessive inflammatory processes. Recent studies suggest a link between allergy and an increased risk of cardiovascular disease, resulting from overactivity of the immune system in allergic diseases and increased synthesis of proinflammatory mediators, which has been well documented in the pathogenesis of atherosclerosis. The aim of this article is to present current data on the role of proinflammatory factors in the pathogenesis of cardiovascular diseases and allergies and on potential relationship between these disorders.
\end{abstract}

Key words: cardiovascular disease; allergy; proinflammatory cytokines

\section{Introduction}

Cardiovascular disease (CVD) is the leading cause of death in developed countries. According to the World Health Organization (WHO) more than 4.5 million people in Europe die due to cardiovascular disease, $44 \%$ of men and $55 \%$ of women (1). Equally important health and social problem in these countries is the occurrence of allergic diseases. It is estimated that allergies occur in up to $40 \%$ of the human population and in more than 80 million Europeans $(2,3)$. Both groups of diseases, due to the very high prevalence and the possibility of serious complications, contribute to a significant deterioration in patients' quality of life and their daily and professional activity.

Pathomechanisms of allergic diseases and cardiovascular events are complex and multifactorial. In most cases cardiovascular disease is acquired, dependent on life-style and usually manifesting after the age of 40. CVD is mainly caused by atherosclerosis, leading to impaired perfusion, ischemia and tissue necrosis. Many risk factors predispose to the development of this disease, including: dyslipidemia, hypertension, diabetes, smoking and pro-inflammatory activity. Definitely less frequent are genetic disorders, predisposing to atherosclerosis, such as familial hypercholesterolemia.

On the contrary, allergy is related to the phenomenon of atopy, which is an innate tendency to excessive IgE synthesis. Atopic diseases result from the hypersensitivity of the immune system to antigens in the environment (plants, fungi and animal allergens, food and cosmetics ingredients), which in healthy people do not cause adverse reactions. Long-term observations have determined that allergies are definitely related to increased levels of inflammatory cytokines. Recent studies indicate the role of interleukin-33, a novel member of IL-1 cytokine family, and its receptor ST2 in distinct disease pathologies: promoting Th2 cells-related inflammation in asthma and allergy as well as exerting atheroprotective effect (4). 
In spite of differences that could allow to exclude the hypothesis about the relationship between CVD and allergy, it is worth to emphasize that the most important element which seems to link both disorders is excessive pro-inflammatory state - on the one hand responsible for the clinical symptoms of allergy, on the other hand associated with the pathogenesis of atherosclerosis.

\section{The role of inflammation in atherosclerosis}

Inflammation plays an important role in all stages of atherogenesis, from the recruitment of leukocytes at the endothelium to the atherosclerotic plaque rupture causing the clinical symptoms of the disease (Figure 1).
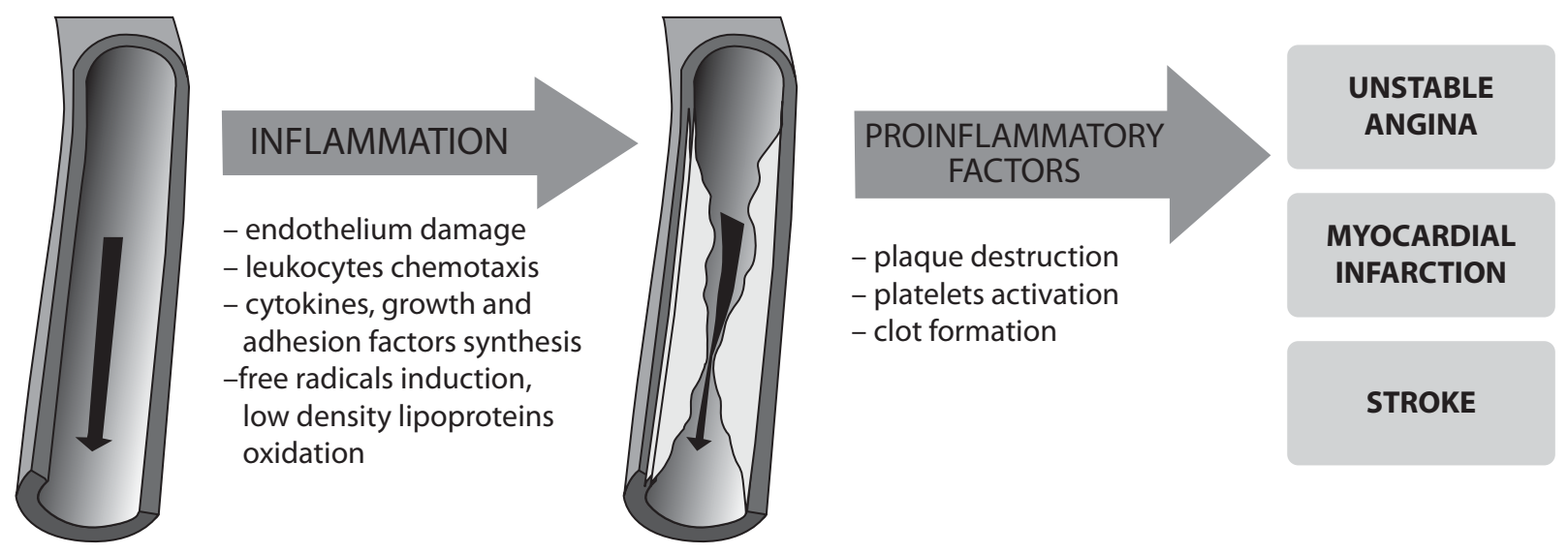

Figure 1. The role of increased inflammation in the pathogenesis of cardiovascular disease.

Atherosclerosis is initiated by endothelial damage due to mechanical, chemical and biological stimuli including: hypertension, dyslipidemia, smoking, viruses and bacteria (for example Chlamydia pneumoniae, Helicobacter pylori) (5). This results in the inflammatory response - stimulation of endothelial cells, macrophages and vascular smooth muscle cells to produce adhesion molecules (VCAM, ICAM, selectin $P$ and $E$ ), which stimulate the recruitment of monocytes into subendothelial space (6). Lipoproteins modified by free radicals are captured in an uncontrolled way by scavenger receptors in macrophages which are transformed to foam cells and infiltrate the intima-media layer. Recently, it was demonstrated that the renin-angiotensin system, particularly angiotensin II, plays an important role in the pathogenesis of atherosclerosis. Angiotensin II, participating in the synthesis of adhesion molecules, inflammatory cytokines and free radicals is one of the enzymes accounting for endothelial dysfunction (7).
Injured endothelium stimulates platelets adhesion and release of their mediators: platelet-derived growth factor (PDGF), endothelin 1, thrombin, transforming growth factor $\beta$ (TGF- $\beta$ ). These substances are involved in vascular myocytes hyperplasia and increased production of extracellular matrix, containing collagen type I and III, elastin, proteoglycans (8). Inflammatory-proliferative changes in the endothelium and the intima lead to pathologic vessel wall remodeling and plaque formation.

Plaque damage leads to the release of coagulation agents such as collagen and tissue factor (TF). This is followed by activation, adhesion and aggregation of platelets and the initiation of coagulation pathways. In addition, plaque rupture results in activation of accumulated $T$ cells and the production of proinflammatory cytokines (IL-6, IL-1, TNF-a) and proteolytic enzymes (metalloproteinases), intensifying the inflammatory response and plaque instability (9). 


\section{The significance of proinflammatory factors in allergy}

Increased inflammatory processes are characteristic for all allergic diseases. This phenomenon is related to the pathological, excessive reactivity of effector cells involved in immune response: T lymphocytes, mast cells, basophils and secreted mediators and cytokines. These substances are responsible for the manifestation of clinical symptoms.

Allergic reactions proceed according to the lgEdependent mechanism of hypersensitivity (type I) (10). Interaction between the allergen (alien antigen) and IgE antibodies residing on the surface of mast cells and basophils causes degranulation and release of mediators: preformed - histamine, tryptase, chymase, carboxypeptidase A (CPA) and synthesized de novo - leukotrienes, prostaglandins
$\mathrm{D}_{2}\left(\mathrm{PGD}_{2}\right)$, platelet-activating factor (PAF) (Figure 2). $\mathrm{Th}_{2}$ lymphocytes regulate the activity of mast cells, basophils and eosinophils and produce cytokines and growth factors (including IL-6, TGF- $\beta$ ). Clinical symptoms are mainly related with biogenic amines (especially histamine) that increase the permeability of blood vessels and cause edema. Histamine causes contraction of smooth muscles of internal organs (like bronchi) (11). Effects of lgEmediated reaction may be either local or systemic anaphylaxis, which is a life-threatening condition. Secreted proinflammatory cytokines stimulate the influx of effector cells and increase both local and systemic symptoms. It should be noted that allergy symptoms appear only after multiple exposure to the allergen, while during the first contact specific IgE directed against specific antigens are produced.
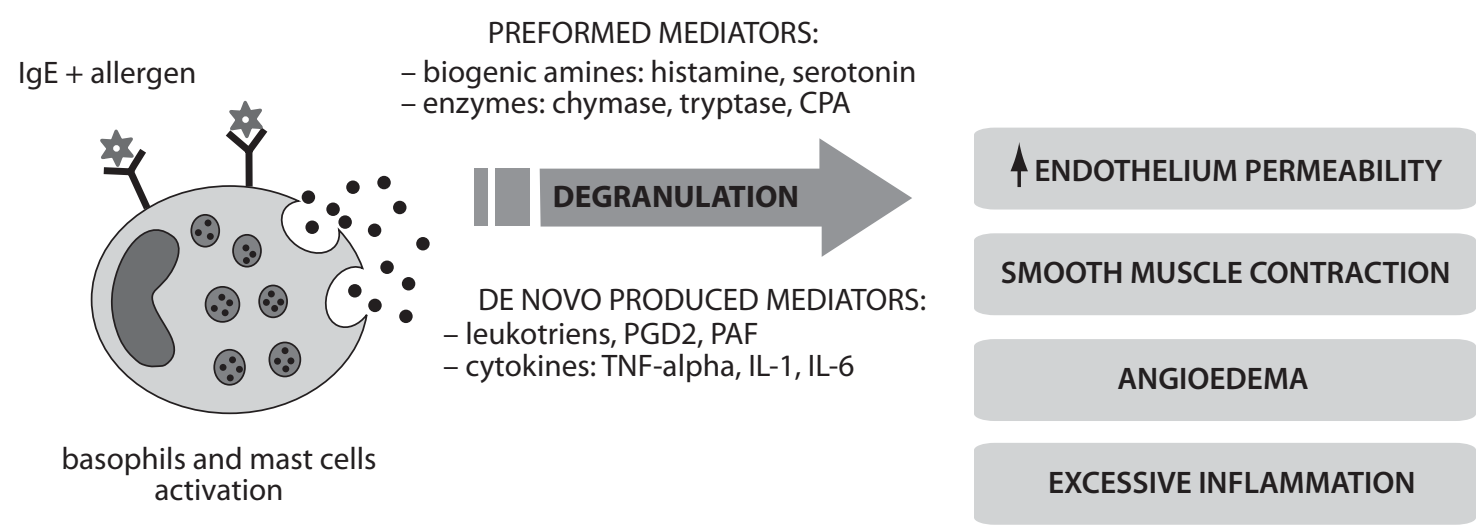

FigURE 2. Mechanism of IgE-dependent reaction and activation of inflammatory factors in allergy.

\section{Inflammation - a common denominator for allergies and increased cardiovascular risk?}

The effect of proinflammatory factors in the pathogenesis of CVD and allergies has been well described and documented in numerous population studies. Although available literature pay limited attention on relationship between these diseases it is worth considering the potential impact of fac- tors involved in the hypersensitivity mechanisms to the cardiovascular system functions.

The task of the immune system is a defense against foreign antigens, recognized as factors potentially pathogenic and harmful - microorganisms, toxins, altered or damaged cells. However, it does not always bring beneficial effects for health, and even a slight deviation can disrupt the proper functioning of the system. It seems that in the case of 
atopic diseases, especially chronic and often occurring exacerbations, excessive activity of stimulated effector cells and induced biochemical reac- tions may be important, although certainly are not the only, potential factors of increased cardiovascular risk (Table 1).

TABLE 1. The potential impact of allergic diseases at increased cardiovascular risk.

\begin{tabular}{|c|c|}
\hline Factors associated with allergic diseases & The potential role in the pathogenesis of CVD \\
\hline $\begin{array}{l}\text { - increased levels of IgE, mast cells and basophils stimu- } \\
\text { lation, secretion of histamine and proinflammatory } \\
\text { cytokines } \\
\text { - increased levels of acute phase proteins (CRP, SAA) }\end{array}$ & $\begin{array}{l}\text { - endothelium damage, leukocytes recruitment, free } \\
\text { radicals induction and oxidation of lipoproteins } \\
\text { - synthesis of metalloproteinases, plaques disruption } \\
\text { and clot formation }\end{array}$ \\
\hline - corticosteroids and $\beta 2$-agonists treatment & $\begin{array}{l}\text { - complications related to extended use: dyslipidemia, } \\
\text { diabetes, hypertension, abdominal obesity (metabo- } \\
\text { lic syndrome components) } \\
\text { - tachycardia, ischemia and heart failure }\end{array}$ \\
\hline - low vitamin D concentration & $\begin{array}{l}\text { increased risk of insulin resistance, diabetes, hyper- } \\
\text { tension, obesity, hypertriglyceridemia - strong CVD } \\
\text { risk factors }\end{array}$ \\
\hline
\end{tabular}

Basophils, mast cells and mediators of IgE-dependent reaction

The contribution of basophils, mast cells and proinflammatory cytokines, including IL-1, IL-6, IL-8, TNF- $\alpha$ and newly discovered IL-33 in hypersensitivity reactions play a key role in atopic diseases such as bronchial asthma and allergic rhinitis $(12,13)$. Significantly increased levels of interleukin- 6 and TNF-a can be observed particularly during exacerbations, and their concentration correlates with the progression of diseases. In recent years much attention has been paid to the participation of these factors not only in immune-related diseases, but also in the process of atherogenesis. Numerous studies indicated excessive accumulation of mast cells in the damaged endothelium which on the one hand stimulate the formation of foam cells and atherosclerotic plaques, and on the other hand is an important element responsible for the degradation of plaques and initiation of coagulation due to cytokines released from the granules and proteolytic enzymes $(14,15)$. Increased levels of both IL- 6 and TNF-a, according to earlier reports, may be used as non-traditional and non-lipid CVD risk factors. The STANISLAS study evaluated a potential relationship between proinflammatory cytokines concentrations and traditional and new atherosclerosis risk factors in a population of young healthy individuals (16). Strong positive correlation was observed between the concentrations of IL- 6 and TNF- $\alpha$ and CRP, as well as the relationship between IL- 6 and adhesion molecules (ICAM-1, L-selectin). Importantly, IL-6 also showed a strong negative correlation with serum concentrations of apolipoprotein A-I and HDL cholesterol which are involved in the reverse cholesterol transport from the blood to the liver and have a strong anti-atherogenic effect. Interestingly, recent reports suggest increased expression of monocyte chemotactic protein (MCP-1) both in allergies and CVD, which induces monocytes and macrophages chemotaxis to the damaged endothelium during atherogenesis and also stimulates the synthesis of IL -1, IL-6 and basophils degranulation in atopic reactions (17). Above mentioned IL-33 is involved in increased secretion of IL-5, IL-10 and IL-13 by Th2 cells which results in macrophages, dendritic cells, mast cells, basophils and epithelial cells activation and is responsible for bronchial spasm and mucus production in asthma patients (4). Though its strong pro-inflammatory activity, several studies have shown that IL-33 has also anti-inflammatory pro- 
perties, which can potentially decrease a cardiovascular risk. IL-33 reduces levels of IFN- $\gamma$ and Th1cell count in lymph nodes due to the suggested switch from Th1 to athero-protective Th2 immune response (18). Moreover, it is a potent anti-atherogenic factor, which inhibits the formation of foamcells by reducing acetylated and oxidized low-density lipoprotein uptake, induces production of nitric oxide and plays beneficial role in homeostatsis of adipose tissue and glucose $(4,19)$. However, it should be considered whether the protective effects of IL-33 are sufficient to offset the pro-inflammatory properties of other cytokines.

Increased levels of biogenic amines, especially histamine released during allergic reaction, responsible for the formation of edema, may also be a predisposing factor for atherosclerosis. Elevated number of mast cells, resulting in an increased concentration of histamine is observed in atherosclerosis outbreaks. Histamine causes loosening of the connections between the endothelial cells, increases their permeability and thus facilitates the inflow of proatherogenic lipoproteins and other substances forming atherosclerotic plaques (20). Growth factors and cytokines, released simultaneously from the activateded mast cells cause increased synthesis of free radicals and changes in the vascular myocytes, which provokes the endothelium injury, proliferation and inflammatory processes. Histamine, through its influence on vascular muscle reactivity, may be associated with perfusion disorders and cardiac arrhythmia.

Recent studies emphasize important role of systemic anaphylaxis in pathologies of the cardiovascular system. The clinical picture of anaphylaxis is dominated by symptoms of cardiac and peripheral circulation, especially hypotension, hemodynamic shock, cardiac arrhythmia and myocardial infarction, which are the most common direct cause of death. This condition is associated with the presence of cardiac mast cells, which differ from peripheral mast cells in their ability to be activated by stimuli other than $\lg \mathrm{E}$, including $\mathrm{C} 3 \mathrm{a}$ and $\mathrm{C} 5 \mathrm{a}$ anaphylotoxins, substance $P$ and eosinophil cationic protein (ECP) (21). Elevated ECP known as a classic exponent of atopic diseases (like asthma) and allergic inflammation in recent years has become the object of interest to cardiologists because of the influence of ECP activity on atherogenesis. Probably ECP may be involved in monocytes adhesion on endothelial cells and in coagulation cascade (22). Moreover, cardiac mast cells are characterized by the secretion of unusually large amounts of mediators, particularly chymase, leukotrienes, $\mathrm{PGD}_{2}$ and $\mathrm{PAF}$, which may induce arrhythmias, decreased coronary flow, myocardial infarction and sudden cardiac death. It is noteworthy that chymase has the potential activity of the angiotensin converting enzyme (ACE) and is able to convert angiotensin I to angiotensin II (Ang II). Although Ang II and its receptor $\mathrm{AT}_{2}$ have documented association with the development of cardiovascular disease as factors causing hypertension and promoting cell growth and apoptosis, pro-oxidant and pro-inflammatory processes $(23,24)$, the role of ACE is not clearly explained yet. The review published by Nawaz et al. summarizes previous findings about the importance of ACE and its polymorphism as a CHD risk factor (25). Increased ACE activity is observed in homozygous deletion D/D genotype, in the opinion of many researchers, is strongly associated with the development of hypertension and atherosclerosis. However, the results from recent studies do not confirm undoubtedly the relationship between polymorphism-related ACE activity and increased cardiovascular risk and certainly require more detailed analysis. Platelets-activating factor plays a dual role in the pathogenesis of CVD - on the one hand promotes leukocytes and macrophages chemotaxis and the secretion of lytic enzymes that damage the atherosclerotic plaques, on the other hand stimulates the aggregation of platelets at the site of injury and clot formation.

\section{Immunoglobulin E and acute phase proteins}

Serum total $\lg E$ ( $\operatorname{tg} \mathrm{E})$, despite the quite small specificity for allergic diseases, is one of the basic laboratory tests used in their diagnosis. It is believed that increased levels of tlgE to $500 \mathrm{IU} / \mathrm{mL}$ is symptomatic of allergies. Jafarzadeh et al. observed the relationship between $\lg \mathrm{E}$ and the occurrence of 
acute coronary syndromes (ACS). In a study of 90 subjects: 30 with acute myocardial infarction, 30 with unstable angina and 30 healthy subjects (control group), higher mean IgE levels were found in ACS patients than in controls (26). In patients with myocardial infarction levels of IgE were significantly higher compared to the control group (367.1 vs. $136 \mathrm{UI} / \mathrm{mL}, \mathrm{P}<0.01)$. Among men, the results also differed significantly, being the highest in men with myocardial infarction, lower in unstable angina and the lowest in control group $(P<0.05)$. The authors explain this phenomenon by interaction of IgE with mast cells and basophiles. Vasoactive substances and cytokines released from the granules of these cells may be an important factor for coronary heart disease. Similar results were recently observed by others in patients suffering from different forms of ischemic heart disease (27). Males with acute myocardial infarction turned out to have significantly higher tlgE concentrations than females and controls.

C-reactive protein, assayed by a high sensitivity method (hsCRP), is a standard parameter to the assessment of mild inflammation. Elevated hsCRP concentrations within 1-3 mg/L and above $3 \mathrm{mg} / \mathrm{L}$ are considered as moderate and high rate of relative risk of CVD. Lin observed high concentrations of CRP (mean $13.9 \mathrm{mg} / \mathrm{L}$ ) in patients with recurrent urticaria and angioedema (28). The relationship between CRP and the severity of clinical symptoms was also found. Sahoo et al. documented higher concentrations of CRP in patients with atopic asthma than in healthy subjects, but the average value was significantly lower than for non-allergic patients with asthma ( 2.9 vs. $8.3 \mathrm{mg} / \mathrm{L}, \mathrm{P}<0.001)$ (29). This may indicate the participation of CRP in inflammatory reactions and suggests a possible lack of association of CRP with allergic asthma. Some authors also suggest a relationship between the prevalence of allergic respiratory disease and an increased concentration of serum amyloid A (SAA) (30). According to The Cardiovascular Risk in Young Finns Study, higher levels of SAA are related to atherosclerosis and metabolic syndrome risk factors, including low concentration of apolipoprotein A-I, HDL-cholesterol, leptin and higher values of BMI, CRP and intima-media thickness (31).

\section{Pharmacotherapy in atopic diseases}

Pharmacological therapy may be an important factor of increased cardiovascular events in allergic patients. The fact is that practically all kinds of allergic diseases are treated by glucocorticoids because of their potent anti-inflammatory and immunosuppressive effects (32). The use of glucocorticoids can reduce the frequency of clinical relapses to a minimum and greatly improve the quality of life. However, discontinuation of treatment generally results in recurrence and exacerbation of allergy symptoms; hence there is a need for their chronic usage. Glucocorticoids, as substances synthesized by the adrenal glands, are involved in the regulation of carbohydrate, protein, lipid and water-electrolyte metabolism. However, prolonged use of exogenous glucocorticoids contributes to serious disturbances in homeostasis, resulting in the development of symptoms such as hyperglycemia, dyslipidemia, abdominal obesity and hypertension, especially in systemic treatment (32). Several studies suggest also a possibility of systemic absorption of topical steroids and incidence of similar side effects $(33,34)$. These disorders are components of metabolic syndrome and strong CVD risk factors (35).

A commonly used algorithm in patients with bronchial asthma is a combination of glucocorticoid and $\beta$-adrenergic receptors agonists that enhance the anti-inflammatory activity and operate a relaxant effect on bronchial smooth muscles, eliminating attacks of breathlessness. Data from recent years stressed that the prolonged use of $\beta$-agonists in patients with asthma and chronic obstructive pulmonary disease (COPD) may increase the risk of cardiovascular disease. In a meta-analysis of 33 studies which included 13 single-dose and 20 of longer duration (from 3 days to 1 year) trials Salpeter et al. observed 2.5 times higher risk of acute coronary syndrome among subjects with asthma and COPD treated with inhaled/nebulized $\beta 2-$ agonists than in the controls (36). The authors suggest that continuous stimulation of $\beta$-adrenergic receptors may lead to ischemia, arrhythmia and heart failure due to an increase rate of myocardial contraction and reduced potassium concentration. 
Recent reports regarding the treatment of allergic diseases indicate the important role of vitamin $D_{3}$ supplementation, especially in children and adolescents. Searing et al. studied serum vitamin $25(\mathrm{OH}) \mathrm{D}$ status in 100 children with bronchial asthma treated with corticosteroids (37). Hypovitaminosis $(<30 \mathrm{ng} / \mathrm{mL})$ and moderate deficiency $(<$ $20 \mathrm{ng} / \mathrm{mL}$ ) was observed in $47 \%$ and $17 \%$ of patients, respectively. A weak but statistically significant negative correlation between 25(OH)D and $\lg E(r=-0.25 ; P=0.01)$ and the number of positive results of allergy skin tests $(r=-0.23 ; P=0.02)$ was noted. Furthermore, a weak significant positive correlation between serum 25(OH)D and the capacity of the lungs was observed. The authors suggest that low concentration of vitamin $25(\mathrm{OH}) \mathrm{D}$ may increase the severity of clinical symptoms of asthma, whereas normal concentration stimulates the action of glucocorticoids. The authors have also concluded that vitamin D supplementation could lead to reduction in drug dose and could improve the health of patients. Consuming adequate amounts of vitamin $D$ and its optimal concentration in the blood (> $30 \mathrm{ng} / \mathrm{mL}$ ) in children and adolescents may reduce the risk of autoimmune diseases, asthma, respiratory infections, as well as hypertension and cardiovascular disease. The optimal threshold for serum vitamin 25(OH)D for nonskeletal health benefits is currently the subject of interest of many studies. The biologically active form of vitamin $\mathrm{D}-1,25(\mathrm{OH})_{2} \mathrm{D}$ is a potent, pleiotropic hormone affecting numerous organs and tissues through binding to its cellular receptors. Vitamin D activates more than 200 genes and modulates gene expression which may suggest its possible role in many other health disorders like diabetes, cancer, multiple sclerosis, hypertension, Alzheimer's disease etc. (38). However, this needs to be confirmed in large prospective studies and welldesigned clinical trials.

NHANES III studies showed a 2-fold higher incidence of hypertension in patients with vitamin $\mathrm{D}$ deficiency. Lower concentration of vitamin $25(\mathrm{OH}) \mathrm{D}$ was also associated with higher risk of diabetes, obesity, hypertriglyceridemia and a higher percentage of mortality from cardiovascular disease (39).

\section{Allergies and CVD risk in recent studies}

At present, the data concerning the assessment of CVD risk in allergic diseases is quite scarce. Described in a few illustrative works $(40,41)$ the relationship between an increased coronary risk and chronic inflammation during allergies have not been so far confirmed by unequivocal results of clinical trials. The recent study of Kim et al. suggests an association between the risk of coronary heart disease (CHD) with commonly occurring symptoms of allergies such as rhinoconjunctivitis (RC) and wheezing (WH) (42). In the group of 8,653 subjects over the age of 20, taking part in the NHANES III in 19881994 the frequency of allergic symptoms was analyzed. CHD was observed in 5.9\% of the surveyed population, nearly in 13\% of patients with $\mathrm{WH}, 5 \%$ with RC and $4 \%$ of healthy individuals. Patients with $\mathrm{WH}$ were characterized by a significantly higher prevalence of hypertension and abdominal obesity and significantly higher average CRP concentration than the other two groups (4.7 vs. 3.7 and 3.9 $\mathrm{mg} / \mathrm{L}$, respectively; $\mathrm{P}=0.008)$. Results of multivariate regression analysis showed a significant correlation between the $\mathrm{WH}$ and the risk of $\mathrm{CHD}$, compared with healthy subjects. After adjusting for other risk factors for CVD, including high blood pressure, total cholesterol, HDL-C and CRP levels and the incidence of type 2 diabetes, a 2.6-fold higher risk of CHD in patients with $\mathrm{WH}$ and $40 \%$ higher risk in the group with RC was noted as compared with controls. The authors explain described relationship by chronic inflammatory response, resulting from excessive synthesis of proinflammatory cytokines in atopic reactions. The most significant differences in test results were observed among women below 50 years of age - probably this condition associated with a higher concentration of estrogen in premenopausal women, which increase the sensitivity of the immune system and activate mast cells and basophils. However interesting results of this study do not show clearly a relationship between allergy and CVD. Moreover, the presence of allergy and coronary heart disease wasn't assessed by diagnostic tests, but by questionnaires, which have relatively low sensitivity and specificity for diagnosis. The authors also indicate that drugs used by patients, especially $\beta$-agonists a 
may have had a significant impact on the results of the analysis.

\section{Conclusions}

The hypothesis of the relationship between allergies and CVD risk is a matter of controversy. It is possible that chronic allergic diseases, and thus long-lasting increased inflammation, reflected by increased levels of proinflammatory cytokines may

\section{References}

1. World Health Organization (WHO): The global burden of disease 2008. Causes of death 2008 - summary tables. Available at: http://apps.who.int/ghodata/?vid=10012. Accessed August 25, 2011.

2. World Allegry Organization (WAO): Allergic Diseases Resource Center. Available at: http://www.worldallergy.org/ public/allergic_diseases_center/overview.php. Accessed October 15, 2010.

3. The European Federation of Allergy and Airways Diseases Patients Associations (EFA): Allergy. Available at: http://www. efanet.org/allergy/index.html. Accessed October 15, 2010.

4. Kurowska-Stolarska $M$, Hueber A, Stolarski B, Mclnnes IB. Interleukin-33: a novel mediator with a role in distinct disease pathologies. J Intern Med 2011;269:29-35.

5. Grabczewska Z, Nartowicz E, Szymaniak L, Wisniewska E, Przybyl R, Polak G, et al. Endothelial dysfunction in acute coronary syndrome without ST segment elevation in the presence of Helicobacter pylori infection. Kardiol Pol 2002;57:537-40.

6. Boyle JJ. Macrophage activation in atherosclerosis: pathogenesis and pharmacology of plaque rupture. Curr Vasc Pharmacol 2005;3:63-8.

7. Sata M, Fukuda D. Crucial role of renin-angiotensin system in the pathogenesis of atherosclerosis. J Med Invest 2010;57:12-25.

8. Aversa A, Basciani S, Visca P, Arizzi M, Gnessi L, Frajese G, Fabbri A. Platelet-derived growth factor (PDGF) and PDGF receptors in rat corpus cavernosum: changes in expression after transient in vivo hypoxia. J Endocrinol 2001;170:395402.

9. Rohde LE, Lee RT. Pathophysiology of atherosclerotic plaque development and rupture: an overview. Semin Vasc Med 2003;3:347-54.

10. Johansson SGO, Hourihane J, Bousquet J, Bruijnzeel-Koomen C, Dreborg S, Haahtela T, et al. (the European Academy of Allergology and Cinical Immunology nomenclature task force). A revised nomenclature for allergy. An EAACI position statement from the EAACI nomenclature task force. Allergy 2001;56:813-24. contribute to pathological changes in the circulatory system. This problem requires further population studies. Hopefully, in the future they will provide valuable insights into the pathogenesis of atherosclerosis and the prevention of cardiovascular disease.

\section{Potential conflict of interest}

None declared.
11. Gorski P. Histamine - a mediator the longer known the more unknown. Alergia 2007;4:33-5.

12. Gorski $P$, Witczak T. Chemokines in allergic inflammation. Alerg Astma Immun 1998;3:23-9.

13. Deo SS, Mistry KJ, Kakade AM, Niphadkar PV. Role played by Th2 type cytokines in IgE mediated allergy and asthma. Lung India 2010;27:66-71.

14. Fairweather D, Frisancho-Kiss S. Mast cells and inflammatory heart disease: potential drug targets. Cardiovasc Hematol Disord Drug Targets 2008;8:80-90.

15. Kovanen PT, Lee M, Leskinen MJ, Öörni K, Lindstedt KA. The mast cell, a rich source of neutral proteases in atherosclerotic plaques. International Congress Series 2004;1262:494-7.

16. Haddy $N$, Sass $C$, Droesch S, Zaiou M, Siest G, Ponthieux $A$, et al. IL-6, TNF- $a$ and atherosclerosis risk indicators in a healthy family population: the STANISLAS cohort. Atherosclerosis 2003;170:277-83.

17. Yadav A, Saini V, Arora S. MCP-1: chemoattractant with a role beyond immunity: a review. Clin Chim Acta 2010;411:1570-9.

18. Miller AM, Xu D, Asquith DL, Denby L, Li Y, Sattar N, et al. IL33 reduces the development of atherosclerosis. J Exp Med 2008;205:339-46.

19. McLaren JE, Michael DR, Salter RC, Ashlin TG, Calder CJ, Miller AM, et al. IL-33 reduces macrophage foam cell formation. J Immunol 2010;185:1222-9.

20. Rozenberg I, Sluka SH, Rohrer L, Hofmann J, Becher B, Akhmedov $A$, et al. Histamine $\mathrm{H} 1$ receptor promotes atherosclerotic lesion formation by increasing vascular permeability for low-density lipoproteins. Arterioscler Thromb Vasc Biol 2010;30:923-30.

21. Triggiani M, Patella V, Staiano Rl, Granata F, Marone G. Allergy and cardiovascular system. Clin Exp Immunol 2008;153(Suppl. 1):7-11.

22. Zrinski Topic R, Dodig S. Eosinophil catonic protein - current concepts and controversies. Biochem Med 2011;21:111-21.

23. Marchesi $C$, Paradis P, Schiffrin EL. Role of the renin-angiotensin system in vascular inflammation. Trends Pharmacol Sci 2008;29:367-74. 
24. Lamarie CA, Schiffrin EL. The angiotensin II type 2 receptor in cardiovascular disease. J Renin Angiotensin Aldosterone Sys 2010;11:19-31.

25. Nawaz SK, Hasnain S. Pleiotropic effects of ACE polymorphism. Biochem Med 2009;19:36-49.

26. Jafarzadeh A, Esmaely Nadimi A, Tajeek H. Serum IgE levels in patients with ischemic heart disease. Iranian Heart Journal 2004;5:20-5.

27. Sinkiewicz W, Blazejewski J, Bujak R, Kubica J, Dudziak J. Immunoglobulin $E$ in patients with ischemic heart disease. Cardiol J 2008;15:122-8.

28. Lin RY. Elevated C-reactive protein (CRP) levels in patients with recurrent urticaria and/or angioedema. Internet Journal of Asthma, Allergy and Immunology. 2002;2. Available at: http://www.ispub.com/journal/the_internet_journal_of_asthma_allergy_and_immunology/archivel volume_2_number_1_4.html. Accessed August 25, 2011.

29. Sahoo RC, Acharua PR, Noushad TH, Anand R, Acharya VK, Sahu KR. A study of high-sensitivity C-reactive protein in bronchial asthma. Indian J Chest Dis Allied Sci 2009;51:213-6.

30. Büyüköztürk S, Gelincik AA, Genç S, Koçak H, Oneriyidogan $Y$, Erden $S$, et al. Acute phase reactants in allergic airway disease. Tohoku J Exp Med 2004;204:209-13.

31. Jylhävä J, Haarala A, Eklund C, Pertovaara M, Kähönen $M$, Hutri-Kähönen $N$, et al. Serum amyloid $A$ is independently associated with metabolic risk factors but not with early atherosclerosis: the Cardiovascular Risk in Young Finns Study. J Intern Med 2009;266:286-95.
32. Saha $S$, Siddiqui S, Bradding P, Holgate ST. A synopsis on pharmacotherapy for allergic diseases. Available at: http:// www.worldallergy.org/professional/allergic_diseases_ center/pharmacotherapy/. Accessed August 25, 2011.

33. Hengge UR, Ruzicka T, Schwartz RA, Cork MJ. Adverse effects of topical glucocorticosteroids. J Am Acad Dermatol 2006;54:1-15.

34. Nieman LK. Consequences of systemic absorption of topical glucocorticoids. J Am Acad Dermatol 201 1;65:250-2.

35. Walker BR. Glucorticoids and cardiovascular disease. Eur J Endocrinol 2007; 157:545-59.

36. Salpeter SR, Ormiston TM, Salpeter EE. Cardiovascular effects of beta-agonists in patients with asthma and COPD: a meta-analysis. Chest 2004;125:2309-21.

37. Searing DA, Zhang Y, Murphy JR, Hauk PJ, Goleva E, Leung $D Y M$. Decreased serum vitamin $D$ levels in children with asthma are associated with increased corticosteroid use. J Allergy Clin Immunol 2010;125:995-1000.

38. Thacher TD, Clarke BL. Vitamin D insufficiency. Mayo Clin Proc 2011;86:50-60.

39. Ozben B, Erdogan $O$. The role of inflammation and allergy in acute coronary syndromes. Inflamm Allergy Drug Targets 2008;7:136-44.

40. Canell JJ, Hollis BW. Use of vitamin D in clinical pratice. Alt Med Rev 2008;13:6-20.

41. Theoharides TC, Kalogeromitros D. Critical role of mast cells in allergy and inflammation. Ann NY Acad Sci 2006;1088:78-99.

42. Kim J, Purushottam B, Chae YK, Chebrolu L, Amanullah A. Relation between common allergic symptoms and coronary heart disease among NHANES III participants. Am J Cardiol 2010;106:984-7.

\section{Postoji li povezanost između alergije i kardiovaskularnih bolesti?}

\section{Sažetak}

Kardiovaskularne bolesti i alergijske bolesti uobičajene su u razvijenim zemljama. One dovode do ozbiljnih zdravstvenih komplikacija i značajno narušavaju kvalitetu života. Oba tipa bolesti karakterizira preintenzivan upalni proces. Novija istraživanja pretpostavljaju da postoji veza između alergije i povećanog rizika od kardiovaskularnih bolesti zbog pretjerane aktivnosti imunološkog sustava kod alergijskih bolesti i pojačane sinteze proupalnih medijatora što se dobro vidi iz patogeneze ateroskleroze. U ovom članku želimo iznijeti trenutne spoznaje o ulozi proupalnih čimbenika u patogenezi kardiovaskularnih bolesti i alergije te podatke o potencijalnoj vezi između tih poremećaja.

Ključne riječi: kardiovaskularne bolesti; alergija; proupalni citokini 